\title{
Effects of Cooperative Learning Strategy and Reasoning on Students Learning Outcomes in Physics
}

\author{
Marungkil Pasaribu \\ Universitas Tadulako \\ Palu, Indonesia \\ pasar67@yahoo.com
}

\author{
Emmi Sianturi \\ SMA Lab Scholl \\ Palu, Indonesia \\ emmisianturi@yahoo.com
}

\begin{abstract}
The purpose of this study was to investigate the effects of cooperative learning and reasoning on student learning outcomes of XI grade students toward physics subject over the six weeks of instruction at SMA Lab Scholl Palu. The design of the study was $2 \times 4$ factorial pre-test, post-test control group design. These included two instructional groups (cooperative and traditional classroom groups) and four reasoning groups (concrete, transitional, pre-formal and formal stage). The students were divided into two matched of 82 to be taught by the same lecturer. In the experimental group was treated by cooperative learning strategy, while in the control group, traditional strategy was employed. To guide this study, three hypotheses stated and tested at 0.05 level of significant. Based on the data analysis, the findings of the studies were as follow: first, there was a significant higher achievement test scores of students in cooperative learning group than those in traditional group. Second, there was a significant difference on students achievement test scores between students with different reasoning stage. Third, there was an interaction effect between learning strategies and reasoning on achievement in physics.
\end{abstract}

Keywords-cooperative learning; reasoning; concrete; transitional; formal; learning outcomes, traditional learning.

\section{INTRODUCTION}

In recent years, studies involving cooperative learning, one kind of student centered approach have emerged as an internationally important area of social science research among researchers. Many studies have been conducted in different setting of education and using different kind of cooperative learning techniques. A series of research studies has found a appreciate relationship between the higher cognitive and affective outcomes and cooperative learning approach. This approach has been reported to improve student achievement, and knowledge retention [1].

Cooperative learning comprises instructional methods in which teachers organize students into small groups, which then work together to help one another learn academic content [2]. It consists of five basic elements: positive interdependence, promote interaction, individual accountability, teaching of interpersonal and social skills and quality of group processing. Positive interdependence means that in cooperative learning situations students are required to work and to learn together as a cohesive group to achieve shared learning objective [3]. In the process, students must be responsible for their own learning and for the success of others group members learning [2]. In other words, students must ensure that other members in their group complete the tasks and achieve the academic outcomes. The lesson will not be cooperative if students do not swim together in the group learning activities [4]. Positive interdependence results in reciprocal interaction among individuals, which promotes each group members productivity and achievement. Promote interaction occurs as individuals encourage and facilitate each other's efforts to accomplish the group's goal. Students are required to interact verbally with one another on learning task. As part of the cooperative learning condition, students are required to interact verbally with one another on learning task, exchange opinions, explain things, teach others and present their understanding [5]. Individual responsibility means that students ask for assistance, do their best work, present their ideas, learn as much as possible, take their tasks seriously, help the group operate well and take care of one another. If there is no individual accountability, one or two group members may do all the work while others do nothing. If the achievement of the group depends on the individual learning of each group member, then the group members are motivated to ensure that all group members master the material being studied [6].

Learning outcomes is determined by the learning process [7]. The learning process is influenced by the subject of learners. The actual learning process takes place at the time of a person's scheme in doubt that stimulates further thinking. Learning results are also influenced by the experience of learners with the physical and environmental world [8]. In response, a cooperative learning was designed for this study in which students different their level of reasoning help each other in heterogeneous groups to perform teamwork-based activities. One aspect deemed important in this context was weather the learning environment designed to reach student with different level of reasoning would allow students to better in their learning outcomes. Given this consideration, this paper investigate the effect of cooperative and traditional learning as an applied learning strategies and the level of student reasoning as a learner characteristic on students learning outcomes in physics. 


\section{METHOD}

This study used a quasi-experimental "Equivalent control group with pretest-posttest" design to identify the effects of Cooperative learning strategy and reasoning on students achievement. The participants of this study were the grade XI students of Lab School in Palu. Two Class $(n=40)$ was randomly chosen to receive Traditional teaching (TT) and acted as the control group, and two class $(n=42)$ received cooperative learning (CL) and acted as the experimental group in physics for 6 weeks. The physics teacher who was assigned to implement both of TT and CL was properly trained before embarking on the task. At the beginning of experiment, students in experimental groups were informed that they would be exposed to CL while the control group would be exposed to TT. The experimental design compared a control group with an experimental group in light two major points: (i) pre-test of student physics achievement and reasoning test was given to both experimental and control groups, (ii) posttest of students physics achievement was given to both experimental and control groups. An achievement test included 45 items in multiple-choice format, and each item had four alternative choices for correct answer. The maximum score for the knowledge component of the achievement test was 45 .

The reasoning levels of the students were measured by Test of Logical Thinking (TOLT) developed by Tobin \& Capie [9]. The students were classified as concrete, transitional, pre-formal and formal level. The 10 test questions involved proportional thinking ( 2 items), control of variable (2 items), probabilistic thinking (2 items), correlational thinking ( 2 items) and combinatorial thinking ( 2 items). Students who scored $0-1$ were classified as concrete reasoner. Scorers of 2 - 3 were classified as transitional reasoner, $4-5$ were classified as pre-formal reasoner while scorers $6-10$ were classified as formal reasoner. Before the experiment commenced, the two groups were pretested on the achievement test.

TABLE I. THE RESULTS OF INDEPENDENT SAMPLES T-TEST

\begin{tabular}{|c|c|c|c|c|c|c|c|c|}
\hline \multirow{2}{*}{$\begin{array}{c}\text { Grou } \\
\text { p }\end{array}$} & \multirow[t]{2}{*}{$\mathbf{N}$} & \multirow{2}{*}{ Mean } & \multirow[t]{2}{*}{ SD } & \multirow{2}{*}{$\begin{array}{c}\text { Mea } \\
\text { n } \\
\text { diffe } \\
\text { renc } \\
\text { e }\end{array}$} & \multicolumn{2}{|c|}{$\begin{array}{l}\text { Levene's } \\
\text { Test for } \\
\text { equality of } \\
\text { variances }\end{array}$} & \multicolumn{2}{|c|}{$\begin{array}{l}\text { t-test for } \\
\text { equality of } \\
\text { means }\end{array}$} \\
\hline & & & & & $F$ & Sig & $t$ & $\begin{array}{c}\text { Sig(2- } \\
\text { tailed } \\
\quad)\end{array}$ \\
\hline $\begin{array}{c}\text { Expe } \\
\text { rimen } \\
\text { tal }\end{array}$ & 42 & 18.97 & 2.66 & \multirow[t]{2}{*}{1.03} & \multirow{2}{*}{$\begin{array}{l}2.3 \\
30\end{array}$} & \multirow[t]{2}{*}{.13} & \multirow{2}{*}{$\begin{array}{l}1.5 \\
95\end{array}$} & \multirow{2}{*}{.115} \\
\hline $\begin{array}{c}\text { Contr } \\
\text { ol }\end{array}$ & 40 & 17.95 & 3.15 & & & & & \\
\hline
\end{tabular}

The results of Independent-samples t-test comparing means of students' physics achievement analysis showed there were no statistically significant difference on pretest scores $(\mathrm{t}=1.595, \mathrm{p}=.115)$ between the treatment group and the control group (Table I). These results indicate that students in both experimental group and the control group had similar pretest scores in physics. A Two way ANOVA analysis was performed to compare the groups' posttest and reasoning level test scores. All analysis were tested for significant at the .05 level.

\section{RESULTS AND DISCUSSION}

\section{A. The Effects Of Cooperative Learning On Students' Learning Outcomes}

Two-way ANOVA analysis were employed to test the effect of learning strategy and reasoning level on student learning outcomes and the results are shown in Table II. Variable of learning strategy shows p-value <.05. These results suggest that there is a significant difference in physics posttest score between the experimental group $(\mathrm{M}=37.64, \mathrm{SD}$ $=3.37)$ and the control group $(\mathrm{M}=35.20, \mathrm{SD}=4.10)$. The magnitude of the difference in the means (means difference $=$ 2.44) was large. The treatment group which had engaged in team work produced higher improvement in scores on physics than the control group. Thus, the finding allows us to conclude that students who are taught by cooperative learning strategies have higher achievement in physics than those taught by lecture based teaching.

The Cooperative learning group shows significant improvement in student achievement in comparison to traditional group. The differences in learning outcomes are predicted due to the cooperative learning strategies have a foundation of students lead discussion that provides opportunities for cognitive apprenticeship or reasoning in the sociocultural context of students. Through student lead discussions there will be cognitive elaboration, peer tutoring, friend modeling and shared assessment and cognitive conflicts that will subsequently affect learning outcomes. Students are involved in discussions with group members or teacher since the beginning of the lesson. Active involvement of students in discussions is essential for developing cognitive thinking skills. Cognitive thinking ability helps students gain learning outcomes in cognitive aspects, especially the higher cognitive aspects of rote learning. Cooperation built between students and students, students and teacher also enhance creativity and support cooperation.

Work together in small group in such a way that everyone can participate in a group task that has been clearly assigned. This component help students in many other ways, such as, in improving their self-concept, self-confidence, and polishing social skills and increased classroom participation [10]. Students took interest in discussion, analysis, and problem solving in difficult physics concepts. This participation increased their interest in physics despite the difficult nature of the concepts. Taking interest is a positive first step towards better performance in achievement tests. The findings of this study, therefore, are consistent with the results are reported by [11-14]. Moreover, the post test results indicate that cooperative learning strategy provide students with the opportunity to determine their concept of the material from the 
laboratory work confidently [15]. Cooperative learning enables students to acquire the appropriate procedural problem solving techniques, and therefore, they were able to solve their problem accurately than the traditional group [16]. Students in traditional group were relative lack of activity. The teaching procedures used in the classrooms were largely expository, which meant that the students were seldom confronted with direct experience in the meaning of many terms introduced. They were passive participants and rarely asked questions. Generally teacher wrote the concepts on the board and then explained them. Students listened and took notes as the teacher lectured on the content.

TABLE II. TWO-WAY ANOVA RESULTS OF POST-TEST

\begin{tabular}{|l|l|l|l|l|l|}
\hline \multicolumn{1}{|c|}{ Source } & $\begin{array}{c}\text { Type III Sum } \\
\text { of Squares }\end{array}$ & Df & Mean Square & \multicolumn{1}{|c|}{ F } & Sig. \\
\hline $\begin{array}{l}\text { Corrected } \\
\text { Model }\end{array}$ & $928.525^{\mathrm{a}}$ & 7 & 132.646 & 31.084 & .000 \\
\hline Intercept & 107943.977 & 1 & 107943.977 & 25295.606 & .000 \\
\hline Group & 108.400 & 1 & 108.400 & 25.402 & .000 \\
\hline Reasoning & 782.517 & 3 & 260.839 & 61.125 & .000 \\
\hline $\begin{array}{l}\text { Group } \\
\text { Reasoning }\end{array}$ & 38.034 & 3 & 12.678 & 2.971 & .037 \\
\hline Error & 315.780 & 74 & 4.267 & & \\
\hline Total & 110197.000 & 82 & & & \\
\hline $\begin{array}{l}\text { Corrected } \\
\text { Total }\end{array}$ & 1244.305 & 81 & & & \\
\hline a. R Squared $=.746$ (Adjusted R Squared =.722) \\
\hline
\end{tabular}

\section{B. The Effect of Reasoning on Student Learning Outcomes.}

Results of the two way ANOVA analysis show there is a significant different in student learning outcomes between each group of reasoning level. The p-value of this variable is less than 0.05. The results showed that the higher student reasoning level the higher their learning out comes. In order to see more clearly the differences in learning outcomes in each reasoning-level group, further testing is done by using Post hoc Tukey test and the results are shown in Table III. The test output yields 4 subsets for $\alpha=0.05$ and each subsets contain a level reasoning. This results stated (1) there is a significant difference in learning outcomes between students who are at the level of concrete reasoning with those at transition, preformal and formal group (2) there is a significant difference in students learning outcomes between transitional group with those at the pre-formal and formal level (3) there is a significant difference in learning outcomes between students who are at the level of pre-formal with formal students.

Based on the formal reasoning skills (TOLT) test, it was found that $20 \%$ of students were in the stage of formal reasoning, $28 \%$ were in the pre-formal, $26 \%$ were in transition operations, and $26 \%$ were in concrete level. This results show that, although the age of students has been in the range of 1617 , only $28 \%$ of them are already in the formal thinking stage. The results of this study similar with the research conducted by Ardhana [17], Scerri [18], and MacKinnon [19]. Bent [20] also stated that there are many university students whose level reasoning are still in concrete operation. The student learning outcomes in each group was $72 \%$ for concrete, $77 \%$ for transition, $86 \%$ for pre-formal and $90 \%$ for formal reasoning. This result indicated the higher reasoning level of the students also the higher in their learning outcomes.

\section{TABLE III. THE POST HOC TUKEY TEST OF REASONING GROUP.}

\begin{tabular}{|l|c|c|c|c|c|}
\hline \multirow{2}{*}{ Reasoning } & \multirow{2}{*}{$\mathbf{N}$} & \multicolumn{5}{|c|}{ Subset } \\
\cline { 3 - 6 } & & $\mathbf{1}$ & $\mathbf{2}$ & $\mathbf{3}$ & $\mathbf{4}$ \\
\hline Concrete & 21 & 32.52 & & & \\
\hline Transitional & 21 & & 34.67 & & \\
\hline Pre-formal & 23 & & & 38.73 & \\
\hline Formal & 17 & & & & 40.41 \\
\hline \multicolumn{1}{|c|}{ Sig. } & 82 & 1.000 & 1.000 & 1.000 & 1.000 \\
\hline \multicolumn{6}{|c|}{ Alpha 0.05.} \\
\hline
\end{tabular}

\section{Interaction between Learning Strategy and Reasoning Level on Student Learning Outcomes.}

The p-value of interaction between learning strategies, reasoning level and student learning outcomes based on two ways ANOVA was found 0.037. This P-value is less than 0.05 so that the statistical decision provides an opportunity to state that there is an interaction effect between the learning strategy and the level of reasoning on the physics learning outcomes. These results suggest that cooperative learning strategies and traditional learning strategies do not have the similar effect on student learning outcomes at each level of reasoning. The difference in student learning outcomes is not only influenced by learning strategies, but also by reasoning levels. In other word the differences in learning strategies and different in levels of reasoning are attributable to the different in learning outcomes students.

In order to analysis the effect of learning strategies and reasoning level on learning outcomes of the students, the statistical test with Post Multiple Comparison Sceffe a, b was used. The analysis displayed 4 subsets for $\alpha=0.05$ as shown in table 5 . Subset 1 is only filled by concrete traditional group with p-value of 1.000 . It can be stated that learning outcomes of students in control group's at concrete level are significantly different from the other group of reasoning ( $\mathrm{p}$-value > .05). The second subset are filled with Traditional Transitional, Cooperative Concrete and Cooperative Transitional with pvalue of 0.707 . This result indicated that learning outcomes of these group were equal and significantly different with another group of reasoning after treatment. The 3rd subsets consist of Cooperative Concrete, Cooperative Transitional and Traditional Pre-Formal with $\mathrm{p}$-value $>.05$ and indicate that these three level of reasoning were equivalent after treatment. The subsets $4^{\text {th }}$ were contain of Traditional Pre-Formal, traditional formal, Cooperative Pre-Formal and Cooperative Formal. The result shows the learning outcomes each level of reasoning with pre-formal and formal stage in control and experiment group were equivalent after treatment. 
The p-value of interaction between learning strategies, reasoning level and student learning outcomes based on Two way ANOVA was found 0.037. This P-value is less than 0.05 so that the statistical decision provides an opportunity to state that there is an interaction effect between the learning strategy and the level of reasoning on the physics learning outcomes. These results suggest that cooperative learning strategies and traditional learning strategies do not have the similar effect on student learning outcomes at each level of reasoning. The difference in student learning outcomes is not only influenced by learning strategies, but also by reasoning levels. In other word the differences in learning strategies and different in levels of reasoning are attributable to the different in student's learning outcomes.

TABLE IV. THE POST MULTIPLE COMPARISON SCEFFE OF INTERACTION BETWEEN LEARNING STRATEGY AND REASONING LEVEL WITH THE LEARNING OUTCOMES

\begin{tabular}{|l|c|c|c|c|c|}
\hline \multirow{2}{*}{ Reasoning Level } & \multirow{2}{*}{$\mathbf{N}$} & \multicolumn{4}{|c|}{ Subset for alpha $=\mathbf{0 . 0 5}$} \\
\cline { 3 - 6 } & & $\mathbf{I}$ & $\mathbf{2}$ & $\mathbf{3}$ & $\mathbf{4}$ \\
\hline Traditional Concrete & 10 & 30.10 & & & \\
\hline $\begin{array}{l}\text { Traditional } \\
\text { Transitional }\end{array}$ & 11 & & 33.73 & & \\
\hline $\begin{array}{l}\text { Cooperative } \\
\text { Concrete }\end{array}$ & 11 & & 34.73 & 34.73 & \\
\hline $\begin{array}{l}\text { Cooperative } \\
\text { Transitional Pre- }\end{array}$ & 10 & & 35.70 & 35.70 & \\
\hline $\begin{array}{l}\text { Traditional Pre- } \\
\text { Formal }\end{array}$ & 12 & & & 38.00 & 38.00 \\
\hline $\begin{array}{l}\text { Cooperative } \\
\text { Formal }\end{array}$ & 8 & & & & 39.42 \\
\hline Traditional Formal & 9 & & & & 39.75 \\
\hline Cooperative Formal & 9 & 1.000 & .707 & .098 & .173 \\
\hline Sig. & & & & \\
\hline
\end{tabular}

In order to analysis the effect of learning strategies and reasoning level on learning outcomes of the students, the statistical test with Post Multiple Comparison Sceffe a, b was used. The analysis displayed 4 subsets for $\alpha=0.05$ as shown in table IV. Subset 1 is only filled by concrete traditional group with p-value of 1.000 . It can be stated that learning outcomes of students in control group's at concrete level are significantly different from the other group of reasoning ( $\mathrm{p}$-value $>.05$ ). The second subsets are filled by Traditional Transitional, Cooperative Concrete and Cooperative Transitional with pvalue of 0.707 . This result indicated that learning outcomes of these group were equal and significantly different with another group of reasoning after treatment. The 3rd subsets consist of Cooperative Concrete, Cooperative Transitional and Traditional Pre-Formal with $\mathrm{p}$-value $>.05$ and indicate that these three level of reasoning were equivalent after treatment. The subsets $4^{\text {th }}$ were contained of Traditional Pre-Formal, traditional formal, Cooperative Pre-Formal and Cooperative Formal. The result shows the learning outcomes each level of reasoning with pre-formal and formal stage in control and experiment group were equivalent after treatment.

\section{CONCLUSION}

In this study, posttest score demonstrated significant differences in learning outcomes between cooperative learning strategies student group with traditional group. Cooperative learning strategies stimulated cognitive activities and promoted higher levels of achievement. However, this strategy was effective only for students whose level in concrete reasoning. The higher the student's reasoning level, the less the influence of this learning strategy on student learning outcomes. For students who have been at the formal reasoning level, their learning outcomes are not influenced by the type of learning strategies.

\section{ACKNOWLEDGMENT}

Pronounced thanks to UNTAD Research Institute, which has funded research in research activities with the Competitive Grant Agreement Number Assignment: 8080/UN28.2/PL/ 2016

\section{REFERENCES}

[1] Tran, V.D. (2014). The effects of cooperative learning on academic achievent and knowledge retention. International Journal of higher education, 3(2)131-140.

[2] Slavin, R.E. 2011. Instruction based on cooperative learning, in R. E. Mayer \& P.A. Alexander (Eds), Handbook of Research on Learning and Instruction (pp. 344-360). New York: Taylor \& Francis

[3] Yager, R. E. 2000. The constructivist Learning model. The science teacher, 67(1), 44-45

[4] Johnson, D.W., \& Johnson, R.T. (2008). Social Interdependence theory and cooperative learning: The teacher's role. In R. M. Gillies, A. Ashman \& J. Terwel (Ed), Teacher's Role in Implementing Cooperative Learning in the Classroom (pp. 9-37). New York, USA: Springer.

[5] Johnson, D.W., \& Johnson, R.T. (2009). An educational psychology success story: Social Interdependence theory and cooperative learning: Educational Researcher, 38(5), 365-379.

[6] Slavin, R. E. 1996. Research on Co-operative Learning and achievent: What we know, what we need to know. Contemporary Educational Psychology, 21, 43-69

[7] Carin, A.A., dan Sund, R. B. 1985. Teaching Science Through Discovery. OHIO. Charles E Merril Publishing Company.

[8] Reigluth, C. M., (Ed). 1983. Instructional Design Theories and Models. New Jersey. Lawrence Erlbaum Associates

[9] Tobin, K. G., and Willia. C. 1980. The development and validation of a group Test of Logical Thinking. Paper presented at the annual meeteng of the American education research association $\left(64^{\text {th }},\right)$. Boston

[10] Zakaria, E., Chin,L.C., \& Daud, Y. 2010. The effects of cooper tive learning on students' mathematics achievement and attitude toward Mathematics. Journal of social sciences, 6(2), 272-275

[11] Gull, F., and Shehzad, S. 2015. Effects of cooperative learning on students' academic achievent. Journal of education and learning, 9(3), 246-255.

[12] Lin, E. 2006. Cooperative Learning in the Science Classroom. The Science Teacher. 73 (5): 34-39

[13] Johnson, D.W., \& Johnson, R.T. (1994). Learning together and alone. London: Allyn and Bacon

[14] Kagan, S. (1994). Cooperative learning. CA: Kagan Pulication Bent, H.A. 1984. Uses of models in teaching chemistry. Journal of Chemical Education. 61 (9): 774-777

[15] Lyle, K. S and Robinson, W. R. 2001. Teaching Science Problem Solving: AN Overview of Experiment. Laboratory Teaching

[16] Lungdren L 1994. Cooperative Learning in The Science Classroom. New York: McGraw Hill Company. 
[17] Ardhana, W. 1987. The ability to think Formal Piaget and the Advancement of Learning in School. Unpublished Disertation: Malang State University.

[18] Sceeri E. R., 2003. Philosophycal Confussion in Chemical Education Research. Journal of Chemical Education. 80(5): 468-473
[19] MacKinnon. G. R., 2004. Why Models Sometmes Fail: Eight Suggestion to Improve Science

[20] Bent, H.A. 1984. Uses of models in teaching chemistry. Journal of Chemical Education. 61 (9): 774-777 